\title{
Forest Restoration Evaluation Through Indicators in Areas of Bauxite Mining
}

\author{
Sabrina Santos Ribeiro ${ }^{1}$ (D), Francisco de Assis Oliveira ${ }^{1}$ (D), \\ Gracialda Costa Ferreira $^{1}$ (D), Daniel Estumano Santos ${ }^{1}$ (D), \\ Denis Conrado $\mathrm{Cruz}^{2}$ (D) \\ ${ }^{1}$ Universidade Federal Rural da Amazônia - UFRA, Belém/PA, Brasil \\ ${ }^{2}$ Universidad de Alcala de Henares - UAH, Alcalá de Henares/Mad., Spain
}

\begin{abstract}
The state of Pará ranks second in Brazilian mineral production, where bauxite accounts for $84 \%$ of total mineral extraction, with negative impacts on the environment as a result. The determination of objectives and targets using environmental indicators as a tool to evaluate forest restoration processes is essential in the recovery of these exploited areas. This study aimed at evaluating the efficiency of forest restoration techniques by means of 13 qualitative and quantitative indicators for monitoring post-bauxite mining operations. Permanent plots were implanted in revegetated areas with the use of two techniques: planting of seedlings and stewarding of natural regeneration. It is concluded that the techniques are efficient for the recovery of forested area. However, natural regeneration showed greater efficiency for restoration for Density, Erosion and Exotic Species indicators. Still, natural regeneration should not be the sole option in the processes of ecosystem restoration, since planting proved to be more efficient for some indicators.
\end{abstract}

Keywords: mining, forest succession, topsoil. 


\section{INTRODUCTION}

Environmental degradation results in negative impacts such as loss of biodiversity, changes in the hydrological cycle, emission of deforestation gases, and especially loss of opportunity for sustainable economic use of the forest, such as the extraction of non-timber forest products (Fearnside, 2006).

Currently, mining is one of the main sources of raw material for industrial processes (IBRAM, 2015). In the municipality of Paragominas, in the state of Pará, bauxite-mining operations began in the 2000s, on the Milônia III plateau, with an initial production estimated at 4.4 million tons p.a. (Brandt, 2003). A licensed mining company has to comply with Brazilian legislation, which includes the miners' responsibility for the environmental recovery of impacted areas (Brasil, 1940, Art. 7, \$2). Thus, a mining entrepreneur must propose a Recovery Plan for Degraded Areas (PRAD) to be approved by the official body licensing his enterprise.

Thus, the recovery of the degraded areas is to follow the mining operations, including the revegetation of the mined plots. The monitoring and verification of the success of the recovery and of the coherence of the actions in the field with what has been established in the Recovery Plan for Degraded Areas follow this. The said Plan should consider the technical solution that is adequate to the specific general circumstances of the site, and should have clear goals and objectives that are linked with the actions on the field, in order to favor the restoration of soil conditions that have been degraded by the mining activity, to provide future use of the resources thereof (IBRAM, 1992).

Concerning this, monitoring methodologies are to be established to search for criteria and indicators that can evaluate the quality of the ecosystem recovery in various Brazilian biomes, and should be not only easily measurable, but sensitive to system stress, predictable, integrative and reliable (Durigan, 2011), taking into account the degradation factor, the specific conditions of each locality, area history, and vegetation dynamics (Andrade et al., 2014).

Therefore, this study aims to evaluate the efficiency of forest restoration techniques (the planting of seedlings and stewarding natural regeneration) by means of monitoring indicators in the bauxite-mining area of Paragominas, in the southeast of Pará state.

\section{MATERIAL AND METHODS}

\subsection{Characterization of the study area}

The research was developed in the municipality of Paragominas, Pará state, in Mineração Paragominas Ltd., (Figure 1), specifically on the Miltônia III plateau, $\left(03^{\circ} 12^{\prime}\right.$ and $03^{\circ} 20^{\prime} \mathrm{S}$ and $47^{\circ} 40^{\prime}$ and $\left.47^{\circ} 46^{\prime} \mathrm{W}\right)$ (Brandt, 2003).

\subsection{Sampling units}

In order to evaluate the indicators, the monitoring data of the area as established in 2009 (terrain reconfiguration and soil deposition) were analyzed. The area is composed of 71.44 ha where the seedling planting technique was used in six permanent plots (PP), and 21.04 ha where the technique of natural regeneration (NR) was used on three plots installed, totaling 92.48 monitored hectares. Data from five monitoring campaigns were used (2013 and 2014 - May and November -, and 2015 - only in May).

In the planting areas, the plots are $20 \times 50 \mathrm{~m}$ $\left(1000 \mathrm{~m}^{2}\right)$ and were evaluated at two sampling levels: Level I $(20 \times 50 \mathrm{~m})$, where all planted individuals were evaluated, and Level II $(10 \times 10 \mathrm{~m})$, in which all plants with a stem diameter $\geq 1 \mathrm{~cm}$ were also evaluated. In the natural regeneration areas, the implanted plots are $10 \times 25 \mathrm{~m}\left(250 \mathrm{~m}^{2}\right)$, where at Level I all individuals were evaluated at $\mathrm{DBH} \geq 10 \mathrm{~cm}$, and at Level II subplots of $5 \times 10 \mathrm{~m}$ all individuals with $\mathrm{DBH}<10 \mathrm{~cm}$ were evaluated.

For the evaluation of the forest litter indicator, the permanent plots installed in the two techniques (planting and natural regeneration), plus other three Evaluation Units in the forest fragment area that did not undergo a direct impact by mining were analyzed, in order to obtain a reference of the quantitative factor of litter to establish a comparison between the techniques.

\subsection{Choice of recovery assessment indicators}

For the selection of indicators the rapid assessment methodologies were used, as cited by Brancalion et al. (2012), and the Pacto pela Restauração da Mata Atlântica - Pact for the Restoration of the Atlantic Forest (Rodrigues et al., 2009) and studies by Salomão et al. (2002) in heterogeneous reforestation in the Saracá Taquera National Forest plateau. 


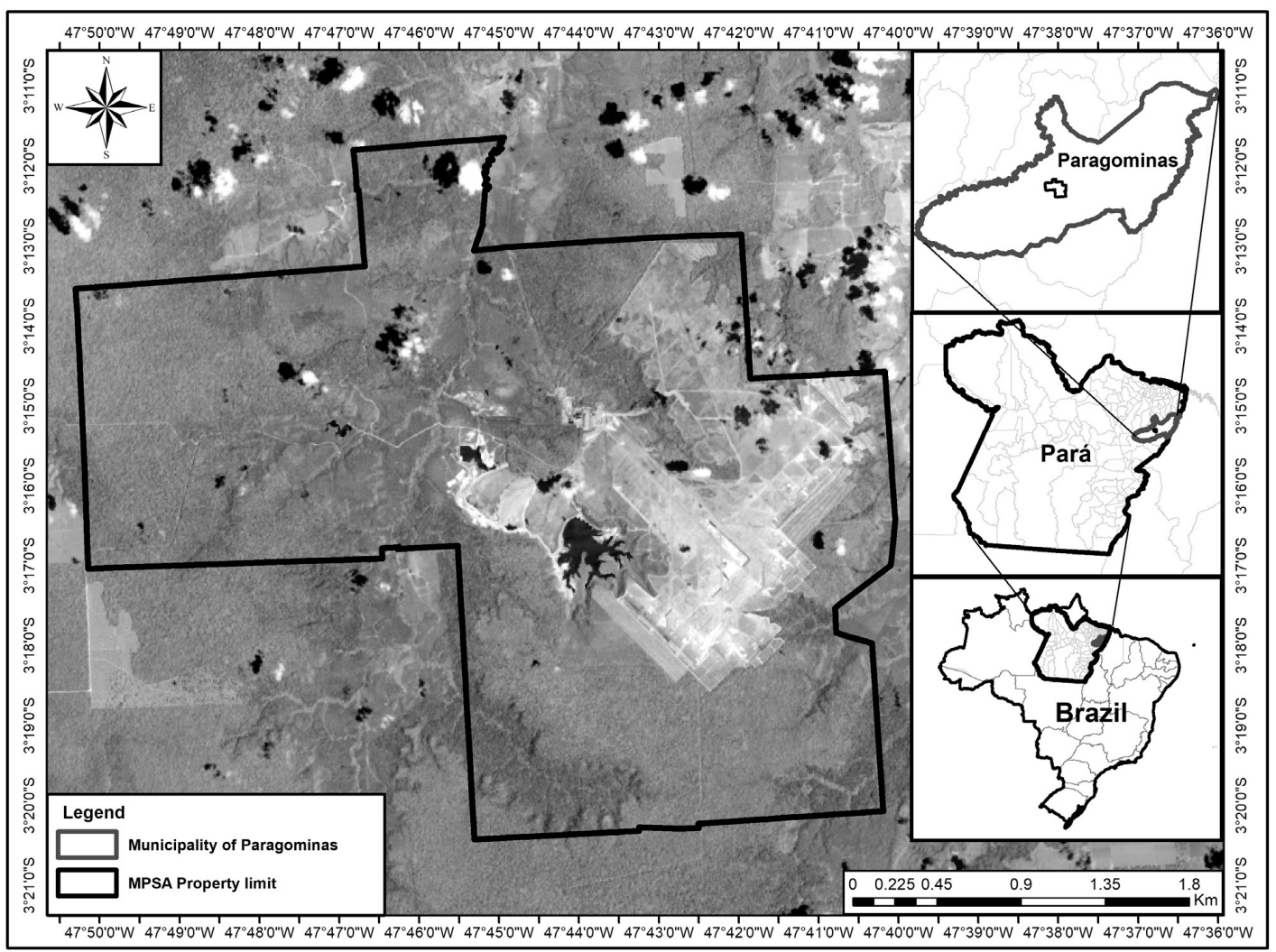

Figure 1. Location of the enterprise where the study was held - Paragominas, Pará state.

The following principles of evaluation in the context of forest restoration in Paragominas were selected: Principle I - evaluation of the structural recovery of the canopy to acknowledge the ecological processes of occupation of the understory in the area through the composition of the species either planted or coming from natural regeneration - and Principle II - monitoring of the ecological trajectory, whose objective is to monitor whether the regeneration dynamics in the area is leading to the restoration within the desired and expected trajectory (Table 1).

\subsection{Collection of information}

The campaigns took place in the months of May and November, with the months from December to May being the most rainy period and from June to November the driest (Andrade, 2011), with dendrometric data collection (total height and circumference) and crown area projection (collection of longitudinal and transverse measurements to calculate the ellipse area), botanical samples were obtained for the floristic data of the registered species. For the quantification of the forest litter stock, a template with width, length and height dimensions of $20 \times 20 \times 7 \mathrm{~cm}$ was used, with the collection place within the vegetation monitoring plots (six random collections).

Qualitative data were obtained in an immeasurable manner, based on the observation of the presence or absence of a certain aspect or phenomenon.

The registered species were herborized and their scientific determination made in the IAN Herbarium of the Eastern Amazonia Embrapa and then sent to the Felisberto Camargo herbarium of the Federal Rural University of Amazonia - UFRA -, since these were mostly non-fertile specimens.

\subsection{Phytosociological analysis}

For the analysis of the horizontal structure, calculations included the parameters of Relative Density (RDe in\%), Relative Frequency (Rf in\%), Relative Dominance (RDo in\%) and Family Importance Value Index (FIV) in\%), which showed information on spatial 
Table 1. Criteria and Indicators used in the evaluation of techniques: planting of seedlings and stewarding natural regeneration in post-bauxite mining areas in Paragominas, Pará state, adapted from Brancalion et al. (2015) and Rodrigues et al. (2009).

\section{EVALUATION INDICATORS} STRUCTURE

\section{DESCRIPTION}

Assess the formation of forest cover in the area

Recovery of Structure and composition Evaluate the resilience power of the area and the vertical and horizontal of vegetation distribution.

Degree of cover/shading Evaluate the percentage of soil cover from the crown shade.

Presence of natural regeneration Evaluate the response of the forest succession process from the seed bank contained in the soil.

Evaluate the presence of laminar erosion, aiming to assess the degree of soil

Presence of erosion conservation.

Forest leaf litter

Density of plants

To evaluate the accumulation of organic matter in the soil, important to determine the viability of plantations that aim at restoring. Evaluate the amount of individuals of shrub and tree species.

Diversity

Average plant height

Basal area

Evaluate the proportion of individuals' distribution between species, calculated by the Shannon diversity index $\left(H^{\prime}\right)$.

Evaluate if the height of the plants is consistent with the age of the individuals. Assess the degree of cover of individuals, or space required by them.

\section{MONITORING ECOLOGICAL} TRAJECTORY

Maintenance of the Area under Monitor the ecological trajectory leading to restoring.

Recovery

Mortality

Increase in Diameter

Presence of non-invasive alien species

Presence of endangered species

Presence of traces of fauna return

To evaluate the dynamics of vegetation growth and mortality and the return of ecological processes.

Evaluate the species that are most adapted to the environmental conditions of the area in the process of restoring.

Quantify the rate of growth of plants.

Evaluate the incidence of regional and exotic species and morphospecies to acknowledge the potential for biological invasion.

Evaluate the species in the threat of extinction level.

Evaluate the return of wild fauna in the area under restoration, identifying traces of animals that act as agents in plant reproduction.

distribution and the importance of plant communities for the ecosystem (Ellenberg \& Mueller-Dombois, 1974). Floristic diversity was also assessed using the Shannon Diversity Index $\left(\mathrm{H}^{\prime}\right)$ on the natural logarithmic basis (Shannon \& Weaver, 1949).

The Shannon-Weaver Index ( $\left.\mathrm{H}^{\prime}\right)$ measures the degree of uncertainty associated with the identity of the species in a sample. Thus, the greater the value of $H$ ', the greater the uncertainty, which can be understood as diversity, and attributes equal weight among rare and abundant species (Magurran, 1989).

\subsection{Criteria for the evaluation of indicators}

In the evaluation, different weights were attributed according to their importance, considering that the indicators of high importance (weight 3) help to understand when processes or phenomena present problems that can compromise the restoration in the short term, making the correction difficult (degree of tree cover/shading, presence of natural regeneration, presence of erosion, forest litter, plant density, diversity, mortality, increase in diameter and the presence of traces of fauna return). The indicators of medium importance (weight 2) indicate problems that can compromise the restoration in the medium term, being easily corrected (mean plant height, basal area and presence of non-invasive alien species). Finally, those of low importance (weight 1) do not compromise the planting, thus being positive indicators, and for this reason should be stimulated (presence of threatened species).

Table 2 shows the definition of the criteria intervals for each indicator as defined in the literature on ecological succession and restoration (Brancalion et al., 2015; Luizão et al., 2014; Salomão et al., 2012; Oliveira, 1998).

Each score was multiplied by the weight of the indicator according to its degree of importance, and it is possible to perform the algebraic sum to define 
the final score in recovery, which was compared to the hypothetical score obtained by an ideal project that reached a maximum score in all the indicators.
Based on this result, the best technique was defined - the one closest to the maximum score for an ideal project (102 points).

Table 2. Evaluation criteria for the analyzed parameters based on the recommendations for restored areas with planting of seedlings and conduction of natural regeneration.

\begin{tabular}{|c|c|c|c|c|}
\hline Indicator & Criterion & Score & Analysis & Reference \\
\hline \multirow{4}{*}{$\begin{array}{l}\text { Degree of tree } \\
\text { cover/shading }\end{array}$} & $<20 \%$ & 0 & \multirow{4}{*}{$\begin{array}{l}\text { Individuals with } \\
\mathrm{DBH} \geq 5.0 \mathrm{~cm}\end{array}$} & \multirow{4}{*}{ Brancalion et al. (2015) } \\
\hline & Between 20 and $50 \%$ & 1 & & \\
\hline & Between 50 and $80 \%$ & 2 & & \\
\hline & $>80 \%$ & 3 & & \\
\hline \multirow{2}{*}{$\begin{array}{l}\text { Presence of natural } \\
\text { regeneration }\end{array}$} & Presence & 3 & \multirow{2}{*}{ Qualitative } & \\
\hline & Absence & 0 & & \\
\hline \multirow{2}{*}{ Presence of erosion } & Presence & 0 & \multirow{2}{*}{ Qualitative } & \\
\hline & Absence & 3 & & \\
\hline \multirow{4}{*}{ Forest leaf litter } & $<4.1 \mathrm{tha}^{-1}$ & 0 & \multirow{4}{*}{$\begin{array}{l}\text { Collection and weighing } \\
\text { of litter }\end{array}$} & \multirow{4}{*}{ Luizão et al. (2014) } \\
\hline & Between 4.1 and $7.7 \mathrm{t} \mathrm{ha}^{-1}$ & 1 & & \\
\hline & Between 7.7 and $9.4 \mathrm{tha}^{-1}$ & 2 & & \\
\hline & $>9.4 \mathrm{tha}^{-1}$ & 3 & & \\
\hline \multirow{4}{*}{ Density of plants } & $<1500$ ind.ha $^{-1}$ & 0 & \multirow{4}{*}{$\begin{array}{l}\text { Individuals with } \\
\text { Height } \geq 50.0 \mathrm{~cm}\end{array}$} & \multirow{4}{*}{ Brancalion et al. (2015) } \\
\hline & Between 1500 and 2000 ind.ha $^{-1}$ & 1 & & \\
\hline & Between 2001 and 3000 ind.ha $^{-1}$ & 2 & & \\
\hline & $>3000$ ind.ha $^{-1}$ & 3 & & \\
\hline \multirow{4}{*}{ Diversity } & $<1.0$ nats ind $^{-1}$ & 0 & \multirow{4}{*}{ All sampled individuals } & \multirow{4}{*}{ Brancalion et al. (2015) } \\
\hline & Between 1.1 and 2.0 nats ind ${ }^{-1}$ & 1 & & \\
\hline & Between 2.1 and 3.0 nats ind ${ }^{-1}$ & 2 & & \\
\hline & $>3.0$ nats ind ${ }^{-1}$ & 3 & & \\
\hline \multirow{4}{*}{ Average height } & $<6.0 \mathrm{~m}$ & 0 & \multirow{4}{*}{$\begin{array}{l}\text { Individuals with } \\
\mathrm{DBH} \geq 5.0 \mathrm{~cm}\end{array}$} & \multirow{4}{*}{ Salomão et al. (2012) } \\
\hline & Between 6.0 and $7.0 \mathrm{~m}$ & 1 & & \\
\hline & Between 7 and 9 m & 2 & & \\
\hline & $>9 \mathrm{~m}$ & 3 & & \\
\hline \multirow{4}{*}{ Basal area } & $<7.0 \mathrm{~m}^{2} \mathrm{ha}^{-1}$ & 0 & \multirow{4}{*}{$\begin{array}{l}\text { Individuals with } \\
\mathrm{DBH} \geq 5.0 \mathrm{~cm}\end{array}$} & \multirow{4}{*}{ Salomão et al. (2012) } \\
\hline & Between 7.0 and $12.0 \mathrm{~m}^{2} \mathrm{ha}^{-1}$ & 1 & & \\
\hline & Between $13.0 \& 19.0 \mathrm{~m}^{2} \mathrm{ha}^{-1}$ & 2 & & \\
\hline & $>19.0 \mathrm{~m}^{2} \mathrm{ha}^{-1}$ & 3 & & \\
\hline \multirow{4}{*}{ Mortality } & $>10 \%$ & 0 & \multirow{4}{*}{$\begin{array}{l}\text { Individuals with } \\
\mathrm{DBH} \geq 5.0 \mathrm{~cm}\end{array}$} & \multirow{4}{*}{ Brancalion et al. (2015) } \\
\hline & Between 5.1 and $10 \%$ & 1 & & \\
\hline & Between 3.1 and 5\% & 2 & & \\
\hline & Between $<3 \%$ & 3 & & \\
\hline & $<0.3 \mathrm{~cm}_{\text {year }}{ }^{-1}$ & 0 & & \\
\hline Increase in & Between 0.3 and $0.5 \mathrm{~cm}$ year $^{-1}$ & 1 & All individuals with & Salomão et al. (2014); \\
\hline Diameter & Between 0.6 and $0.7 \mathrm{~cm}_{\text {year }}{ }^{-1}$ & 2 & 5 measurements & Oliveira (1998) \\
\hline & $>0.7 \mathrm{~cm}_{\text {year }}{ }^{-1}$ & 3 & & \\
\hline Presence of & Presence & 0 & Oualitative & Brancalion et al (2015) \\
\hline $\begin{array}{l}\text { non-invasive anten } \\
\text { species }\end{array}$ & Absence & 3 & Quantative & Brancallon el al. (2015) \\
\hline Presence of & Presence & 3 & & Brancalion et al (2015) \\
\hline endangered species & Absence & 0 & Qualitative & Brancalion et al. (2015) \\
\hline Presence of traces of & Presence & 3 & Oualitative & \\
\hline & Absence & 0 & Qualitative & \\
\hline
\end{tabular}

Source: Adapted from Brancalion et al. (2012). 


\section{RESULTS AND DISCUSSIONS}

\subsection{Floristics and phytosociology}

Of the 542 individuals (from seedlings) monitored in May 2015, 371 individuals (1,293.3 ind.ha $\left.{ }^{-1}\right)$ in the planting of seedlings belong to 106 species (67 genera and 24 botanical families), while in natural regeneration 171 individuals $\left(8,733.3\right.$ ind.ha $\left.{ }^{-1}\right)$ are distributed in 27 species ( 22 genera and 16 botanical families).

In the areas of planting of seedlings, the Family Importance Value Index - FIV - showed Solanaceae with $23.2 \%$, Malvaceae with $26.5 \%$ and the most expressive was Fabaceae, with $135.6 \%$. For Fabaceae, higher numbers of species are recorded in the Brazilian flora (Forzza et al., 2010). This family is important in ecological restoration strategies because of its association with nitrogen-fixing bacteria (Sprent, 2001).

In the areas under natural regeneration there was a better balance between the values found for FIV. The three families that stood out were Urticaceae with $38.8 \%$, Fabaceae with $40 \%$, and Hypericaceae with $46.9 \%$ of FIV (13 families found in the survey). Although Hypericaceae did not show the largest number of species (1 species), it obtained the largest number of individuals (1907 ind.ha ${ }^{-1}$ ) and basal area (3.61 $\left.\mathrm{m}^{2} \mathrm{ha}^{-1}\right)$.

In the planting of seedlings and in natural regeneration, the 12 families with the highest importance value index totaled $274.02 \%$ and $242.0 \%$, respectively, of a maximum total of $300 \%$ of FIV, ratifying the ecological importance of these to the fauna and flora balance of the ecosystem that undergoes a process of restoration.

\subsection{Restoration of vegetation structure and composition}

\subsubsection{Diversity of species}

The value of the Shannon index for the planting area recorded a mean value of $3.3 \pm 0.2$ for all sample units, while in natural regeneration the mean value was $2.2 \pm 0.3$. This result was already expected due to the number of species used in planting (147 species), while in natural regeneration there is a dependence on the germination of the seed bank contained in the soil and the dispersion of seeds from surrounding areas.
The result obtained for the H' index was below that recorded by Francez et al. (2007), which was 4.25 for managed forests in the municipality of Paragominas, and by Knight (1975), who found the range of the $\mathrm{H}^{\prime}$ index for the Amazon rainforest between 3.83 and 5.85, which characterize high diversity forests. According to Rodrigues \& Gandolfi (2000), the recolonization of altered areas may have different floristic diversity and composition from the original one, which may affect the characteristics of the forest structure, depending on the degree of intervention. Comparison of the means through the $t$ test at $95 \%$ probability showed that there was a significant difference $(p<0.05)$ between the evaluated methods.

\subsubsection{Density of plants}

The mean confidence interval for density in the area planted to seedlings was 975 ind.ha $^{-1} \pm 447.6$, lower than that found in natural regeneration, which was 8,400 ind.ha $^{-1} \pm 2,540.2$. The comparison of the means by the t test $(\alpha=0.05)$ indicated a significant difference between the evaluated methods $(p<0.05)$. This result can be explained by silvicultural treatments in the area of planting, such as: hoeing, crowning, ant control, influencing the development of regenerant individuals.

The emergence of species in a given area after its abandonment depends essentially on the available seed bank, which is influenced by the surrounding area conditions, taking into account the phenology of the species and the presence of dispersers transiting between these areas (Massoca et al., 2012).

\subsubsection{Basal area}

The mean value for the basal area in natural regeneration was $13.6 \mathrm{~m}^{2} \mathrm{ha}^{-1} \pm 9.81$, higher than that found for planting seedlings of $2.9 \mathrm{~m}^{2} \mathrm{ha}^{-1} \pm 0.7$. The comparison of the means through the $t$ test $(\alpha=0.05)$ showed a significant difference between the evaluated methods $(p<0.05)$.

The basal area is used to verify disturbances or changes in the environment, since it evaluates the forest structure, which tends to reach stability more quickly when the measurements of species composition are compared (Letcher \& Chazdon, 2009). In the secondary succession processes, high basal area values are expected in the intermediate phase due to the high density and increment in diameter (Chazdon, 2012). 


\subsubsection{Average height}

The average height value obtained for the planting of seedling was $5.2 \pm 0.5$, while for natural regeneration it was $5.1 \pm 0.42$. The comparison of averages using $t$ test $(\alpha=0.05)$ showed there is no significant difference between the assessed methods ( $p>0.05)$. In the planting of seedlings, $76.4 \%$ of sampled individuals are equal or below $5.0 \mathrm{~m}$ height and $83 \%$ of natural regeneration individuals are within the same height class.

\subsubsection{Degree of cover}

The degree of cover of the planting area recorded average values that were $49.5 \% \pm 17.6$, higher than the average crown cover found in natural regeneration, which was $23 \% \pm 9.1$. The comparison of averages using a t test $(\alpha=0.05)$ showed there is no significant difference as to soil cover between the assessed methods ( $\mathrm{p}>0.05)$.

The crown cover in the forest is a determining factor of the microclimate, impacting the growth and permanence of plantlets; weed encroachment through the reduction of luminosity on the soil - a determining factor for the floristic composition, affecting oxidizing processes of organic matter and controlling erosive processes (Melo et al., 2007).

The method for crown projection measurement did not prove to be practical, and demanded too much time, in addition to its inaccuracy due to the shape variation of the crowns that do not form a perfect ellipse.

According to Carnevale \& Montagnini (2002), the understory shading by the crown of planted trees reveals a positive correlation with both density and richness of natural regeneration. Accordingly, the results found for this indicator corroborate what was verified for the density indicator, inasmuch as it was expected to find a positive relation between the number of individuals and the degree of cover.

\subsubsection{Forest leaf litter}

The total stock of forest leaf litter on the soil at the seedling planting area was of $10.1 \mathrm{Mg} \cdot \mathrm{ha}^{-1}+2.28$, a value that is close to the one found on the natural regeneration area of $10.5 \mathrm{Mg} \cdot \mathrm{ha}^{-1}+1.13$, both values are inferior to the quantity found for the surrounding Dense Ombrophilous Forest, of 12.1 Mg.ha ${ }^{-1}+2.42$. These values coincide with several studies performed in the Brazilian Amazon on secondary forests with ages from 5 to 22 years, which according to Luizão et al. (2014) vary between 4.47 and $9.40 \mathrm{Mg} \cdot \mathrm{ha}^{-1}$. However, according to Luizão (2007), the forest leaf litter production may vary considerably in time, mainly depending on the abiotic variables.

The comparison of averages using t test $(\alpha=0.05)$ showed there is no significant difference for the quantity of forest leaf litter present in the three assessed areas $(p>0.05)$. The similarity between the environments may be related to climate conditions since the areas are in close proximity with little meteorological variation (Dickow et al., 2012).

\subsubsection{Qualitative analysis}

In the planting of seedlings, soil erosion soil was present in one of the assessed plots (17\%), whilst in natural regeneration no erosion was identified. One of the possible causes of erosion may be the terrain reconfiguration process, which is not carried out in level curves, driving more sediment to lower areas, in addition to manual weeding performed two years after implementation of planting, removing regenerant individuals.

Salomão et al. (2014) reported that high-density planting and induction of natural regeneration are the most recommended practices for recovering degraded fragments. Therefore, the spacing used in planting $(3 \times 3 \mathrm{~m})$ may have impacted the erosion process, since it does not promote a swift coverage of the soil. In the natural regeneration areas, higher soil coverage is observed, thus avoiding the driving and leaching.

In the planting of seedlings, natural regeneration was identified but in one sample unit, totalizing $83 \%$ of plots with the presence of regenerant individuals.

The regenerant individuals' response is directly related to the germinating capacity of the seed bank. According to the operational initial procedure for mining operations, the topsoil that is removed from suppression areas must be directly transported to recovery areas, ensuring there is no deposit of soils impacting the seeds' germinating power. In the case of this study, reports from the company indicate that the deposited topsoil was stored for four months before being spread, which could have impacted the loss of the species' germinating capacity.

According to Salomão et al. (2013), the selection of species for planting implementation is important for the 
community structure (abundance, spatial distribution, biomass, scale or cover) since this selection impacts the occurrence of the other species and consequently, the successful recovery of areas that were degraded by open-air mining.

\subsection{Maintenance of the area under recovery}

\subsubsection{Mortality}

The average mortality rate in the planting of seedlings was of $10.3 \% \pm 4.5$ per year. The period of higher mortality rate was in May 2014, with $16.2 \%$, and the lowest mortality rate was observed in May 2015 , with 5.3\%. A study held in the 1980's and 1990's by Salomão et al. (2002) recorded a mortality below $10 \%$ over a two-year period of heterogenic reforesting operations on the Saracá Taquera plateau between 1996 and 1998.

In the area were the natural regeneration stewarding technique was implemented, the average mortality rate was of $15.5 \% \pm 7.9$. The lowest mortality rate was observed in the monitoring performed in November 2013, with 7.0\%, and the highest rate was identified during the monitoring of November 2014, with 25.2\%. The comparison of averages using t test $(\alpha=0.05)$ showed there is no significant difference in mortality rates between the two assessed techniques ( $p>0.05)$.

\subsubsection{Annual periodic diameter increment}

The annual periodic increment in diameter in the seedling planting area was $1.09 \mathrm{~cm}_{\text {year }}{ }^{-1} \pm 0.28$, while in the natural regeneration area the increment was $1.71 \mathrm{~cm}$ year $^{-1} \pm 0.48$. The comparison of averages using t test $(\alpha=0.05)$ showed there is a significant difference between the assessed methods $(p<0.05)$.

A study carried out by Salomão et al. (2014) in a 13-year reforestation process analyzing 69 species has found an average increment value between $0.01 \mathrm{~cm}_{\text {year }}{ }^{-1}$ and $2.5 \mathrm{~cm}$ year $^{-1}$, a higher value than the one found in this study. Also in Saracá Taquera, Salomão et al. (2006) found an average annual increment value of $1.02 \mathrm{~cm}$ year $^{-1}$, varying between $0.26 \mathrm{~cm}_{\text {year }}{ }^{-1}$ and $3.24 \mathrm{~cm}$ year $^{-1}$.

\subsubsection{Presence of exotic and threatened species}

Of the 106 species recorded in the seedling planting area, only two species were considered as exotic: Bauhinia macrophylla and Bauhinia purpurea (JBRJ,
2015), because they are not featured in the Brazilian flora. In the natural regeneration areas, no exotic species were found.

Exotic species must be controlled in areas under restoration in order to allow and stimulate the development of the more desired native species (TNC, 2013). Native species, particularly those of interest for the restoration, must be favored with actions such as the application of agroforestry treatment (fertilization, ant control, etc.), which might improve their development and stabilizing in the process of populating.

Regarding threatened species, the Red List of Threatened Species created by the International Union for Conservation of Nature (IUCN, 2004), the Official List of Threatened Species from the Brazilian Flora published by Ministry of Environment in Ordinance $n^{\circ}$. 443/2014 (Brasil, 2014), and the List of Threatened Species in the State of Pará published in the appendix of COEMA Resolution no. 54/2007 (COEMA, 2007), were consulted. Fifteen threatened species were found in the planting areas (Amburana cearensis, Aspidosperma álbum, Astronium graveolen, Bauhinia rufa, Cedrela fissilis, Enterolobium schomburgkii, Genipa americana, Hymenaea courbaril, Hymenaea parvifolia, Inga laurina, Lecythis lurida, Parkia ulei, Pterocarpus santalinoides, Swietenia macrophylla and Zollernia paraensis) and two species in the natural regeneration areas (Hymenaea courbaril and Hymenaea parvifolia). In the natural regeneration areas, such fact is highly positive considering that the seed bank and/or dispersion process are favoring the natural forthcoming of such species, which is important for their perpetuation.

\subsubsection{Signs of wildlife recovery}

For this indicator, traces of feces of Tapirus terrestris (South-American Tapir), listed as vulnerable in the IUCN list of threatened species, were found in planting areas, as well as Mazama americana (red brocket); while in the natural regeneration area, no traces were found in the samples units.

The wildlife indicator results are essential for the understanding of plant and animal interaction with the purpose of studying the genetic diversity within populations of tree species by means of the genic flow that takes place with pollination and seed dispersion, which are impacted by the process of fragmentation and then recovery of the areas (Machado et al., 2006). 
Table 3. Overall evaluation of the indicators analyzed in forest restoration area after bauxite mining in Paragominas-PA.

\begin{tabular}{|c|c|c|c|c|c|c|c|c|}
\hline \multirow{2}{*}{ Code } & \multirow{2}{*}{ Indicator } & \multirow{2}{*}{$\begin{array}{l}\text { Weight - } \\
\text { Degree of } \\
\text { relevance }\end{array}$} & \multirow{2}{*}{$\begin{array}{l}\text { Indicator } \\
\text { Maximum } \\
\text { Score }\end{array}$} & \multirow{2}{*}{$\begin{array}{c}\text { Maximum } \\
\text { Final } \\
\text { Score }\end{array}$} & \multicolumn{2}{|c|}{$\begin{array}{l}\text { Planting of } \\
\text { Seedlings }\end{array}$} & \multicolumn{2}{|c|}{$\begin{array}{c}\text { Natural } \\
\text { Regeneration }\end{array}$} \\
\hline & & & & & $\begin{array}{l}\text { Obtained } \\
\text { Score }\end{array}$ & $\begin{array}{l}\text { Final } \\
\text { Score }\end{array}$ & $\begin{array}{c}\text { Obtained } \\
\text { Score }\end{array}$ & $\begin{array}{l}\text { Final } \\
\text { Score }\end{array}$ \\
\hline \multicolumn{9}{|c|}{ RECOVERY OF THE VEGETATION STRUCTURE AND COMPOSITION } \\
\hline A.1 & Diversity & 3 & 3 & 9 & 3 & 9 & 2 & 6 \\
\hline A.2 & Plant Density & 3 & 3 & 9 & 0 & 0 & 3 & 9 \\
\hline A.3 & Basal Area & 2 & 3 & 6 & 0 & 0 & 3 & 6 \\
\hline A.4 & Average Height & 2 & 3 & 6 & 0 & 0 & 0 & 0 \\
\hline A.5 & Degree of Coverage & 3 & 3 & 9 & 2 & 6 & 2 & 6 \\
\hline A.6 & Forest Leaf Litter & 3 & 3 & 9 & 3 & 9 & 3 & 9 \\
\hline A.7 & Presence of erosion & 3 & 3 & 9 & 0 & 0 & 3 & 9 \\
\hline A. 8 & Presence of natural regeneration & 3 & 3 & 9 & 3 & 9 & 3 & 9 \\
\hline B & \multicolumn{8}{|c|}{ MAINTENANCE OF THE RECOVERY AREA } \\
\hline B.1 & Mortality & 3 & 3 & 9 & 0 & 0 & 0 & 0 \\
\hline B. 2 & Diameter Increment & 3 & 3 & 9 & 3 & 9 & 3 & 9 \\
\hline B.3 & Presence of Exotic Species & 2 & 3 & 6 & 0 & 0 & 3 & 6 \\
\hline B.4 & Presence of Threatened Species & 1 & 3 & 3 & 3 & 3 & 3 & 3 \\
\hline B.5 & Signs of Wildlife Recovery & 3 & 3 & 9 & 3 & 9 & 0 & 0 \\
\hline Final & Score & & & 102 & & 54 & & 72 \\
\hline
\end{tabular}

\subsection{Overall evaluation of both indicator-based techniques}

The consolidation of scores obtained for each technique has showed that the stewarding of natural regeneration (72 points) presented a higher score in comparison with the planting of seedlings (54 points), of the total score that would be obtained for a perfect project (102 points) (Table 3). Despite the difference, both techniques show satisfactory results for the recovery of areas after bauxite mining, provided a few adjustments are made.

The results show that some items must get more attention so that the goal may be met within the planned period, demonstrating the importance of monitoring and the application of assessment methods in order to enable the timely identification and correction of problems to establish sustainable restored forests (Brancalion et al., 2012).

According to Sánchez (2010), the recovery of mined areas takes into account the regulation of physical aspects and the restoration of the biotic environment, of which he lists four environment scenarios to be considered: topographic, edaphic, hydric and vegetative practices.
Brancalion et al. (2015) stated that one of the main problems in the restoration process is the definition of clear goals in assessing and monitoring so as to obtain a set of results that can be successfully interpreted at different moments of the trajectory. Studies must work towards establishing reliable and adequate indicators for each local reality.

\section{CONCLUSIONS}

The applied indicators showed that both techniques assessed were efficient in recovering bauxite mined areas, whereas natural regeneration in the overall evaluation showed a higher efficiency for density, did not present erosion or exotic species in its areas. However, it should not be the sole technique to be used in ecosystem restoration processes, since in some indicators the planting of seedlings was more efficient (diversity and signs of wildlife recovery).

\section{ACKNOWLEDGEMENTS}

The authors are greatful to Universidade Federal Rural da Amazônia - UFRA, Universidade Federal do Pará - UFPA, Museu Emílio Goeld - MPEG, Universidade de Oslo (BRC00003) and Hydro Paragominas. 


\section{SUBMISSION STATUS}

Received: 28 july, 2017

Accepted: 15 jan., 2018

\section{CORRESPONDENCE TO}

\section{Sabrina Santos Ribeiro}

Instituto de Ciências Agrárias - ICA, Universidade Federal Rural da Amazonia UFRA, Av. Presidente Tancredo Neves, 2501, Terra Firme, CEP 66077-530, Belém, PA, Brasil e-mail: sabrinaflorestal@hotmail.com

\section{REFERENCES}

Andrade FS. Variabilidade da precipitação pluviométrica de um município do estado do Pará. Revista Engenharia Ambiental: Pesquisa e Tecnologia 2011; 8(4): 138-145.

Andrade GF, Sanchez GF, Almeida JR. Monitoramento e avaliação em projetos de recuperação de áreas degradadas. Revista Internacional de Ciências 2014; 4(2): 13-26.

Brancalion PHS, Gandolfi S, Rodrigues RR. Restauração florestal. São Paulo: Oficina de Textos; 2015.

Brancalion PHS, Viani RAG, Rodrigues RR, Gandolfi S. Avaliação e monitoramento de áreas em processo de restauração. Viçosa: UFV; 2012.

Brandt. Relatório de impacto ambiental da empresa Mineração Bauxita Paragominas. Ananindeua; 2003.

Brasil. Decreto-Lei no 1985, de 29 de março de 1940. Código de Minas de 1940. Diário Oficial da República Federativa do Brasil [online], Brasília, DF (1940 mar.) [cited 2017 Jan 20]. Available from: http://www.jusbrasil.com.br/ legislacao/111067/codigo-de-minas-de-1940-decretolei-1985-40

Brasil. Ministério de Meio Ambiente - MMA. Portaria MMA $n^{\circ} 443$, de 17 de dezembro de 2014. Homologa alista Nacional Oficial de Espécies da Flora Ameaçadas de Extinção no Estado do Pará. Diário Oficial da República Federativa do Brasil, Brasília, DF (2014 dez.).

Carnevale N, Montagnini F. Facilitating regeneration of secondary forests with the use of mixed and pure plantations of indigenous tree species. Forest Ecology and Management 2002; 163(1-3): 217-227. http://dx.doi. org/10.1016/S0378-1127(01)00581-3.

Chazdon R. Regeneração de florestas tropicais Tropical forest regeneration. Boletim do Museu Paraense Emílio Goeldi. Ciências Naturais 2012; 7: 195-218.

Conselho Estadual de Meio Ambiente - COEMA. Resolução COEMA $n^{\circ}$ 54, de 24 de outubro de 2007. Homologa a lista de espécies da flora e da fauna ameaçadas no Estado do Pará. Diário Oficial [online], Belém, PA (2007 out.) [cited 2017 Jan 20]. Available from: https://www.sema. pa.gov.br/2007/10/24/10059/

Dickow KM, Marques R, Pinto CB, Höfer H. Produção de serapilheira em diferentes fases sucessionais de uma floresta subtropical secundária, em Antonina, PR. Cerne 2012; 18(1): 75-86. http://dx.doi.org/10.1590/S010477602012000100010 .

Durigan, G. O uso de indicadores para monitoramento de áreas em recuperação. Cadernos da Mata Ciliar 2011; 4: 11-13.

Ellenberg D, Mueller-Dombois D. Aims and methods of vegetation ecology. New York: Wiley; 1974.

Fearnside PM. Desmatamento na Amazônia: dinâmica, impactos e controle. Acta Amazonica 2006; 36(3): 395-400. http://dx.doi.org/10.1590/S0044-59672006000300018.

Forzza RC, Baumgratz JFA, Bicudo CEM, Carvalho AA Jr, Costa A, Costa DP et al. Catálogo de plantas e fungos do Brasil. Rio de Janeiro: Jardim Botânico do Rio de Janeiro; 2010. (vol. I-II).

Francez LMB, Carvalho JOP, Jardim FCS. Mudanças ocorridas na composição florística em decorrência da exploração em uma área de floresta de terra firme na região de Paragominas, PA. Acta Amazonica 2007; 37(2): 219-228. http://dx.doi.org/10.1590/S0044-59672007000200007.

Instituto Brasileiro de Mineração - IBRAM. Mineração e meio ambiente. Brasília; 1992. 126 p.

Instituto Brasileiro de Mineração - IBRAM. Informações sobre a economia mineral brasileira [online]. Brasília; 2015 [cited 2016 Feb 18]. Available from: http://www.ibram. org.br/sites/1300/1382/00005836.pdf

International Union for Conservation of Nature - IUCN. Red List of threatened species: IUCN Species Survival Commission [online]. Cambridge: IUCN; 2004 [cited 2015 Aug 13]. Available from: www.redlist.org

Jardim Botânico do Rio de Janeiro - JBRJ. Reflora: lista de espécies da flora do Brasil. Rio de Janeiro: Jardim Botânico do Rio de Janeiro; 2015 [cited 2015 Apr 21]. Available from: http://floradobrasil.jbrj.gov.br/

Knight DH. A phytosociological analysis of speciesrich tropical forest on Barro Colorado Island, Panama. Ecological Monographs 1975; 45(3): 259-284. http://dx.doi. org/10.2307/1942424.

Letcher SG, Chazdon RL. Rapid recovery of biomass, species richness, and species composition in a forest chronosequence in Northeastern Costa Rica. Biotropica 2009; 41(5): 608-617. http://dx.doi.org/10.1111/j.17447429.2009.00517.x.

Luizão F. Ciclos de nutrientes na Amazônia: respostas às mudanças ambientais e climáticas. Ciência e Cultura 2007; 59(3): 31-36. 
Luizão F, Pashanasi-Amasifuen B, Del Castillo-Torres $\mathrm{D}$, Lavelle P. Influência da massa e nutrientes da liteira sobre a composição dos macro-invertebrados em plantíos florestais na Amazônia peruana. Folia Amazónica 2014; 23(2): 171-186. http://dx.doi.org/10.24841/fa.v23i2.22.

Machado ELM, Gonzaga APD, Macedo RLG, Venturin $\mathrm{N}$, Gomes JE. Importância da avifauna em programas de recuperação de áreas degradadas. Revista Científica Eletrônica de Engenharia Florestal 2006; 4(7): 3-9.

Magurran AE. Diversidad ecologica y su medición. Espanha: Ediciones Vedra; 1989. 199 p.

Massoca P, Jakovac A, Bentos T, Williarnson G, Mesquita R. Dinâmica e trajetórias da sucessão secundária na Amazônia Central. Boletim do Museu Paraense Emílio Goeldi. Ciências Naturais 2012; 7(3): 235-250.

Melo ACG, Miranda DLC, Durigan G. Cobertura de copas como indicador de desenvolvimento estrutural de reflorestamentos de restauração de matas ciliares no médio vale do Paranapanema, SP, Brasil. Revista Árvore 2007; 31(2): 321-328. http://dx.doi.org/10.1590/S010067622007000200015 .

Oliveira LC. Dinâmica de crescimento e regeneração natural de uma floresta secundária no Estado do Pará. In: Ecology and Management of Tropical Secondary Forest: Science, People, and Policy: Proceedings of a Conference Held at CATIE; 1997; Costa Rica. Costa Rica: Bib. Orton IICA/CATIE; 1998. p. 69. (vol. 4).

Rodrigues RR, Gandolfi S. Conceitos, tendências e ações para a recuperação de florestas ciliares. In: Rodrigues RR, Leitão HF Jr, editors. Matas ciliares: conservação e recuperação. São Paulo: Universidade de São Paulo; 2000. (vol. 1)

Rodrigues RR, Lima RAF, Gandolfi S, Nave AG. On the restoration of high diversity forests: 30 years of experience in the Brazilian Atlantic Forest. Biological Conservation 2009; 142(6): 1242-1251. http://dx.doi.org/10.1016/j. biocon.2008.12.008.
Salomão RP, Brienza S Jr, Rosa NA. Dinâmica de reflorestamento em áreas de restauração após mineração em unidade de conservação na Amazônia. Revista Árvore 2014; 38(1): 1-24. http://dx.doi.org/10.1590/S010067622014000100001 .

Salomão RP, Matos AH, Rosa NA. Dinâmica de reflorestamentos visando a restauração da paisagem florestal em áreas de mineração na Amazônia. Boletim do Museu Paraense Emílio Goeldi. Botânica 2002; 18(1): 157-194.

Salomão RP, Rosa NA, Castilho A, Morais JAC. Castanheirado-brasil recuperando áreas degradadas e provendo alimento e renda para comunidades da Amazônia Setentrional. Boletim do Museu Paraense Emílio Goeldi. Ciências Naturais 2006; 1(2): 65-78.

Salomão RP, Santana AC, Brienza S Jr. Seleção de espécies da floresta ombrófila densa e indicação da densidade de plantio na restauração florestal de áreas degradadas na Amazônia. Ciência Florestal 2013; 23(1): 139-151. http:// dx.doi.org/10.5902/198050988448.

Salomão RP, Vieira ICG, Brienza S Jr, Amaral DD, Santana AC. Sistema Capoeira Classe: uma proposta de sistema de classificação de estágios sucessionais de florestas secundárias para o estado do Pará. Boletim do Museu Paraense Emílio Goeldi. Ciências Naturais 2012; 7: 297-317.

Sánchez LE. Planejamento e gestão do processo de recuperação de áreas degradadas. In: Filippini-Alba JM, editor. Recuperação de áreas degradadas: a visão dos especialistas brasileiros. 2. ed. Pelotas: Embrapa Clima Temperado; 2010.

Shannon CE, Weaver W. The mathematical theory of communication. Urbana: University of Illinois Press; 1949.

Sprent JI. Nodulation in legumes. Kew: Royal Botanical Gardens; 2001. 146 p.

The Nature Conservancy - TNC. Manual de restauração florestal: um instrumento de apoio à adequação ambiental de propriedades rurais do Pará. Belém: The Nature Conservancy; 2013. 128 p. 